\title{
Review on monitoring natural and environmental radiation and its potential from mining products
}

\author{
Imam Ghazali Yasmint ${ }^{1}$, Sidik Permana ${ }^{1}$ \\ ${ }^{1}$ Nuclear Physics Laboratory, Nuclear Physics and Biophysics Research Group, \\ Department of Physics, Faculty of Mathematics and Natural Science, \\ Bandung Institute of Technology, \\ Ganesha No. 10 Bandung 40132, Indonesia
}

( Received: September 28,2021, Revised: October 9, 2021, Accepted: November 14, 2021 )

\begin{abstract}
Monitoring of natural radiation in Indonesia has been carried out by various parties, from researchers, academics at universities to special agencies tasked with handling this matter, such as the National Nuclear Energy Agency (Batan) and the Nuclear Energy Supervisory Agency (Bapeten). Batan through the Center for Radiation Safety and Metrology Technology (PTKMR) is in charge of monitoring natural radiation at the national level. The purpose of this paper is to review the monitoring of natural and environmental radiation in Indonesia and the potential of mining products as a source of natural radiation. The mining products that will be reviewed in this paper are natural uranium and thorium which are usually found in several mines, such as tin mines and others.
\end{abstract}

Keywords: Radiation monitoring, Thorium, Uranium

\section{INTRODUCTION}

As of December 31, 2017, 448 power reactors were in operation worldwide with a total power capacity of $392 \mathrm{GW}(\mathrm{e})$. In addition, 797 research reactors have been built in 67 countries in the world. Research reactors are indispensable for providing radioisotopes for medical and industrial applications, neutron beams for research materials and non-destructive testing, teaching and training of radiation workers and other uses [1]. With so many nuclear reactors operating in the world, both power reactors and research reactors, as well as the application of nuclear technology in all fields, it can have a negative impact in the form of releasing radioactive materials into the environment [2]. The release of radioactive material into the environment is one of the results of the use of artificial radioactive substances. In addition, there are also natural sources of radiation that have existed naturally and have occurred since the formation of the earth. Natural radiation activity in the environment around us, among others, comes from exposure to terrestrial radiation and radon gas as well as radiation from outside the earth in the form of cosmic radiation. Terrestrial radiation exposure can be sourced from nuclear minerals, namely mining products containing radionuclides such as uranium and thorium [3].

According to the UNSCEAR (2000) report, natural radiation is the largest contributor to radiation sources received by humans, about $85 \%$ of the total radiation received by humans in one year [4]. Based on this, it is also important to monitor natural radiation in an area. Monitoring of natural radiation is carried out by mapping the natural radiation of certain areas, so that areas with radioactivity anomalies are found [5]. One of the objectives of radiation monitoring is to control radiation levels in an area and make decisions about potential hazards caused by natural radiation [6].

Monitoring of natural radiation in Indonesia has been carried out by various parties, from researchers, academics at universities to special agencies tasked with handling this matter, such as the National Nuclear Energy Agency (Batan) and the Nuclear Energy Supervisory Agency (Bapeten). Batan through the Center for Radiation Safety and Metrology Technology (PTKMR) is in charge of monitoring natural radiation at the national level. It aims to collect radiation level data and make it a basic data of natural radiation in Indonesia so that it can be used for analysis of nuclear leaks and accidents [7]. The

\footnotetext{
* Corresponding author

E-mail address: imamghazaliyasmint@gmail.com
} 
purpose of this paper is to review the monitoring of natural and environmental radiation in Indonesia and the potential of mining products as a source of natural radiation. The mining products that will be reviewed in this paper are natural uranium and thorium which are usually found in several mines, such as tin mines and others.

\section{RADIATION SOURCES}

The radiation dose received by a person can come from various sources. According to data from UNSCEAR in 2000, an average person receives a dose of $2.8 \mathrm{mSv}$ per year [4]. Radiation sources can come from natural sources and artificial sources.

Table 1. Percentage Origin of Radiation Dose [4].

\begin{tabular}{|c|c|c|}
\hline \multirow{2}{*}{ Sources } & \multicolumn{2}{|c|}{ Dose } \\
\cline { 2 - 3 } & mSv & $\%$ \\
\hline Natural Background Radiation \\
\hline Cosmic Rays & 0.4 & 14.25 \\
\hline $\begin{array}{c}\text { Terrestrial Gamma } \\
\text { Rays }\end{array}$ & 0.5 & 17.81 \\
\hline Internal & 0.3 & 10.69 \\
\hline Inhalation (Radon) & 1.2 & 42.75 \\
\hline $\begin{array}{c}\text { Natural Background } \\
\text { Radiation }\end{array}$ & 2.4 & 85.49 \\
\hline \multicolumn{2}{|c|}{ Man-made Radiation } \\
\hline $\begin{array}{c}\text { Diagnostic Medical } \\
\text { Examination }\end{array}$ & 0.4 & 14.25 \\
\hline Nuclear Power Plant & 0.0002 & 0.01 \\
\hline $\begin{array}{c}\text { Atmospheric } \\
\text { Nuclear Testing }\end{array}$ & 0.005 & 0.18 \\
\hline Chernobyl Accident & 0.002 & 0.07 \\
\hline $\begin{array}{c}\text { Man-made } \\
\text { Radiation }\end{array}$ & 0.4072 & 14.51 \\
\hline Total & 2.8 & 100 \\
\hline
\end{tabular}

\subsection{Natural Radiation Source}

Natural radiation and radioactivity are found everywhere on earth. Learning and research about radiation and natural radioactivity is very important for the science of radiation physics. This is due to several reasons, namely radiation and natural radioactivity initiated the discovery and development of various atomic models, nuclear structures and radioactive transformations, continuous exposure by natural sources will be a reference for considering the level of natural radiation protection, discovery and use of uranium, thorium and radon and the transformation product is needed to understand the radiological impact that will be produced and every measurement of radioactivity in a sample must know the background radiation that occurs naturally so that the measurement is more precise and reliable [8].

Natural radiation consists of cosmic rays and naturally occurring radioactive materials. These materials are cosmogenic (cosmogenic radionuclides), primordial or arise due to the radioactive transformation of other substances. Cosmic radiation is radiation that comes from the sun and other sources inside and outside the Milky Way galaxy. The radiation is in the form of cosmic rays. Cosmic rays have very high energy consisting of $87 \%$ protons, $11 \%$ alpha particles, $1 \%$ electrons and the rest are heavy atoms. When they hit the atmosphere, cosmic rays undergo nuclear interactions with materials in the atmosphere to produce secondary particles associated with the production of cosmogenic radionuclides [8].

Cosmic ray radiation received by the world's inhabitants on earth depends on geographical latitude and altitude. People living at high latitudes receive a higher level of effective radiation dose than people living at low latitudes. Aircrews and pilots will receive a relatively high annual dose compared to people living on earth. A study reported having measured gamma radiation and neutrons by placing dosimeters on a number of aircraft. His observations show that for a flight time of 600 hours at an altitude of 10,000 meters it gives a dose rate of about $3 \mathrm{mSv} / \mathrm{year}$ while at an altitude of 18,000 meters it gives a dose rate of about 0.15 $\mathrm{mSv}$ /hour [7]. According to the UNSCEAR report (1988), the average dose received by flight crew on a 4-year flight is about $2.5 \mathrm{mSv} / \mathrm{year}$ with the possibility of receiving a maximum dose level of around $15 \mathrm{mSv} /$ year [9].

Cosmogenic radionuclides are produced by the interaction of high-energy protons $(87 \%$ from cosmic radiation) with elements from the atmosphere. This interaction produces high-energy neutrons which interact again with elements in the atmosphere to produce several radionuclides such as $\mathrm{H}-3, \mathrm{Be}-7, \mathrm{C}-14, \mathrm{Na}-22$ and so on. The interacting neutrons mostly come from the atmosphere which is a cosmic ray interaction. This is because radioactive free neutrons can only last for 12 minutes and not long enough to travel from space. The concentration of neutrons in the atmosphere increases with increasing altitude to a maximum of 40,000 feet and then decreases [8].

Cosmic ray interactions can also occur on the surface of the ocean or the earth. But more dominant interactions occur in the atmosphere. The neutron flux density at sea level is only 30 neutrons $/ \mathrm{cm} 2 \mathrm{~h}$ with only 8 being thermal neutrons. Therefore, the production of radionuclides due to neutron capture that occurs in the ocean and the earth's crust is very small [8]. The annual effective dose of cosmogenic radionuclides was reported by UNSCEAR in 2000. For the $\mathrm{C}-14$ nuclide the dose is $12 \mathrm{~Sv}$, for the Na-22 nuclide the dose is $0.15 \mathrm{~Sv}$, for the $\mathrm{H}-3$ nuclide the dose is $0.01 \mathrm{~Sv}$ while for $\mathrm{C}$ - 
14 requires attention more because it can come from artificial radiation sources. Overall, the annual effective dose of cosmic radiation is 0.3 $\mathrm{mSv}-1.0 \mathrm{mSv}$ with a mean of $0.4 \mathrm{mSv}$ [4].

Gamma radiation from natural radiation sources comes from natural radionuclides contained in building materials, mining products, soil, plants and other environmental elements. Building materials commonly used for houses such as bricks, cement, sand, ceramics, and gypsum contain natural radionuclides from the uranium (U238), thorium (Th-232) and potassium-40 (K-40) series, which are derived from in the earth [10]. A decay series is a series of radioactive decays from an unstable radionuclide to a more stable radionuclide. In this series of decays, various kinds of decay will occur with a very long time and produce various other radionuclides until they eventually decay into stable radionuclides. In nature, the decay series is divided into four groups, namely the uranium (U) series starting at U-238 and ending with $\mathrm{Pb}-206$, the thorium (Th) series starting at Th-232 and ending with $\mathrm{Pb}-208$, the actinium series starting from Th-232 and ending with $\mathrm{Pb}-208$. from $\mathrm{U}-235$ and ending by $\mathrm{Pb}-207$ and the neptunium series starting at Np-237 and ending by $\mathrm{Bi}-209$. In addition to neptunium, the parent radionuclides in the natural decay series are primordial radionuclides because of their long life and still exist 4.5 billion years after the formation of the solar system. The primordial source of Np237 no longer exists because of its half-life of only 2.1 million years [8].

\subsection{Artificial Radiation Source}

Artificial radiation is produced from human activities, such as medical activities, nuclear experiments, nuclear power plants (NPP). This activity will result in nuclear fission radionuclides, such as Sr-90, Cs-137, I-131, Zr-95, and $\mathrm{Kr}-85$, and activations such as Co-60, C-14, and $\mathrm{N}-14$. In contrast to natural radiation sources, artificial radiation sources are easier to control, because natural radiation sources occur continuously and are difficult to control. However, its spread to the environment needs to be monitored through environmental monitoring [7].

Artificial radiation has two very different uses in the medical field - for diagnosis and therapy. Both are intended to benefit the patient and, as with any use of radiation, the benefits must outweigh the risks. Most people at some point in their lives undergo X-ray examinations to help physicists diagnose disease or damage in the body.
A less common diagnostic procedure involves administering a radionuclide to the patient so that an outside detector can be used to observe how the organ is functioning. Physicists use one of these procedures if they cannot make a diagnosis without it. The radiation dose is generally low, although it can be quite large in certain procedures. Much higher doses are needed to treat malignant disease or dysfunctional organs, sometimes in combination with other forms of treatment. The use of X-rays to examine patients is called diagnostic radiology and the use of radionuclide labeled drugs for diagnosis or therapy is called nuclear medicine. When beams of radiation are used to treat patients, the procedure is called radiotherapy [11].

When a nuclear weapon is tested above ground, it pushes a variety of radionuclides from $\mathrm{H}-3$ (tritium) to $\mathrm{Pu}-241$ into the upper atmosphere. From there, the radionuclides are transferred slowly to the lower atmosphere and then to the Earth's surface. About 500 atmospheric explosions were carried out before the limited test ban treaty came into effect in 1963, with several more explosions until 1980. Radionuclide concentrations in air, rain and human food are now much lower than peak values in the early 1960s [11]. In the period 1945-1998, there have been 2039 nuclear weapons explosion tests [12].

\section{NATURAL URANIUM AND THORIUM AS POTENTIAL SOURCES OF NATURAL RADIATION}

\subsection{Uranium}

\subsubsection{Physical, Chemical and Decay Properties of Uranium}

Uranium is a naturally occurring element that makes up about 2-4 ppm of the Earth's crust. It is more abundant than silver and almost as much as molybdenum or arsenic. Uranium is an actinide element, and has the highest atomic mass of any naturally occurring element. In its fine state, a silvery-white metal that is malleable, ductile, slightly paramagnetic, and very dense, second only to tungsten. In nature, it is found in rocks and ores throughout the earth. In its natural state, crustal uranium occurs as a component of some minerals, such as carnotite, uraninite, and mixed ores, but is not found in the metallic state [13].

Metallurgically, uranium metal may exist in three allotropic forms: orthorhombic, tetragonal, or body-centered cubic [14], and can be mixed with 
other metals to change their structural and physical properties to suit the application. Like aluminum metal powder, uranium metal powder is autopyrophoric and can ignite spontaneously at room temperature in the presence of air, oxygen, and water [13].

Uranium can be found in five oxidation states: $+2,+3,+4,+5$, and +6 [14]. However, only the +4 and +6 states are stable enough to be of practical interest. Tetravalent uranium is quite stable and forms hydroxides, hydrated fluorides, and phosphates of low solubility. Hexavalent uranium is the most stable state, and the most common state is $\mathrm{U}_{3} \mathrm{O}_{8}$, although there are several local storage sites for anthropogenic uranium hexafluoride $\left(\mathrm{UF}_{6}\right)$ in the United States. The main compounds of uranium include oxides, fluorides, carbides, nitrates, chlorides, acetates, and others. One of the characteristics of the $\mathrm{UO}_{2}{ }^{+2}$ ion is its ability to fluoresce under ultraviolet light [13].

Uranium found in nature consists of three radioactive isotopes, namely $\mathrm{U}-238, \mathrm{U}-235$ and $\mathrm{U}-$ 234. Only U-235 can undergo fission reactions and makes up $0.7 \%$ of the total mass of natural uranium. Meanwhile, U-238 is the most abundant isotope, i.e. $99 \%$ of the total mass of natural uranium [15]. The decay scheme of U-238 can be seen in Figure 1.

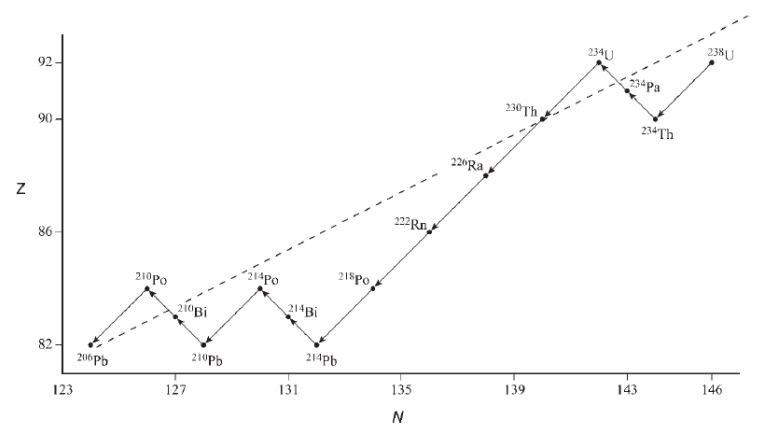

Figure 1. U-238 decay series [8].

The uranium decay series can be divided into several important subsections. Some of them are U-238 itself, Th-230, Ra-226, Rn-222 and Pb210. Th-230 decays from its precursor in seawater and collects on the ocean floor. A precursor is a nuclide that precedes another nuclide in a series or schema. Th-230 is usually used to predict the age of rocks on the seabed. In addition, Th-230 is also commonly found during uranium processing and is the source of Ra-226 and Rn-222 [8].

$\mathrm{Ra}-226$ is often found isolated from its precursors. When in natural waters, Ra-226 and other isotopes move and settle like some of the deposits often found around hot springs. Ra-226 emits minimum gamma energy during its decay process. But it will increase as the children fall to reach equilibrium. Rn-222 is the only gaseous nuclide in the U-238 series. Rn-222 is produced from Ra-226 and can be easily separated from its parent due to its gas phase. $\mathrm{Pb}-210$ is a decaying child of transformed radon and is the last subsection of the U-238 series. It can usually be observed in the atmosphere to appreciable concentrations [8].

\subsubsection{Uranium Deposit}

Based on the TECDOC IAEA-1629, there are several definitions of uranium found in nature, namely Uranium Occurrence which is an anomalous concentration of uranium that occurs naturally, Uranium Deposit which is a natural mineral mass where uranium can be exploited at this time or in the future and Initial (Global) Resource which is the total amount of uranium in the deposit before the production process occurs. In addition to the definition of uranium, uranium resources are also divided into several categories, namely Reasonably assured resources (RAR), Inferred resources (or also known as estimated additional resources EAR), Identified resources, Prognosticated resources and Speculative resources (SR) [16].

In simple terms, RAR is the resource contained in the most well-known part of a deposit whereas EAR refers to the lesser known material associated with the same deposit. Both categories relate to identifiable resources such as previously explored and estimated reserves. Both systems are based on cross-sections of existing drilling or mining tests with different levels of extrapolation from real data [17]. Identified resources are reasonably assured resources plus inferred resources. Prognosticated resources refer to uranium, in addition to inferred resources, that are expected to occur in deposits for which the evidence is largely indirect and which is believed to exist within well-defined geological trends or areas of mineralization with known deposits. Speculative resources (SR) refers to uranium, other than prognosticated resources, that are thought to exist, based largely on indirect evidence and geological extrapolation, in deposits that can be found by existing exploration techniques [16].

Uranium resources can be defined based on their geological arrangement into categories of uranium ore deposits, namely (arranged according 
to their estimated economic significance) unconformity related deposits, sandstone deposits, hematite breccia complex deposits, quartzpebble conglomerate deposits, vein deposits (granite related deposits), intrusive deposits, volcanic and caldera related deposits, metasomatite deposits, surficial deposits, collapse breccia pipe deposits, phosphorite deposits, rock types with elevated uranium contents and other deposits [16].

Unconformity related deposits relate to and occur just below and above the unconformable contacts that separate the intensively altered crystalline crypt from the overlying clastic sediments of the Proterozoic age. Sandstone deposits occur in medium to coarse grained sandstone that was deposited in a continental or marginal fluvial marine sedimentary environment. Uranium is deposited under reducing conditions caused by various reducing agents in the sandstone, for example, carbonaceous materials, sulfides (pyrite), hydrocarbons and ferro-magnesium (chlorite) minerals, etc. Hematite breccia complex deposits occur in hematite-rich breccia containing uranium associated with copper, gold, silver and rare earths. The main deposit is the Olympic Dam deposit in South Australia. Detrital uranium oxide ores are found in quartz pebble conglomerate deposits deposited as basal units in fluvial to lacustrine flow systems older than 2.3-2.4 Ga. The conglomerate matrix is pyritiferous and gold, and other detrital oxide and sulfide minerals are often present in small amounts. Examples include deposits found in the Witwatersrand Basin where uranium is mined as a byproduct of gold [16].

In vein deposits, the major part of the mineralization fills fractures of varying thickness, and extension is generally important along strike. Veins consist of gangue materials (e.g. carbonates, quartz) and ore materials, primarily pitchblende. Intrusive deposits are associated with intrusive or anatectic rocks with different chemical compositions (alaskite, granite, monzonite, peralkaline syenite, carbonatite and pegmatite). Volcanic and caldera related deposits are located in and around volcanic calderas filled with mafic to felsic volcanic complexes and intercalated clastic sediments. Mineralization is largely structurally controlled (minor stratabound), occurs at several stratigraphic levels of volcanic and sedimentary units and extends to basements where it is found in fractured and metamorphic granite. Uranium minerals are commonly associated with molybdenum, other sulfides, purple fluorine, and quartz. The most significant commercial deposits are located within the Streltsovsk caldera in Russia. Metasomatite deposits are confined to areas of

tectonomagmatic activity of the Precambrian shield and are associated with alkaline metasomatite near faults, which developed over different bedrock. The ore has a thickness of several meters to tens of meters and a length of several hundred meters. The vertical area of ore mineralization can be up to $1.5 \mathrm{~km}$. The ores commonly found are uraninite-brannerite with the composition and belong to the ordinary class [16].

Surficial deposits are broadly defined as the concentration of young near-surface uranium (tertiary to present) in sediments and soils. The largest surficial deposits are in calcrete (calcium and magnesium carbonates) and have been found in Australia (the Yeelirrie deposit), Namibia (the Langer Heinrich deposit) and Somalia. Collapse breccia pipe deposits occur in circular vertical pipes filled with falling fragments. Uranium is concentrated as primary uranium ore, generally uraninite, in a permeable breccia matrix, and in the ring fault zone surrounding the pipe. This deposit is only found in the USA. Phosphorite deposits consist of marine phosphate containing stratiform syn-sediment, disseminated uranium in finegrained apatite. Phosphorite deposits are a large uranium resource, but at very low levels. Uranium can be recovered as a by-product of phosphate production [16].

Based on the TECDOC IAEA-1629, several comparisons of uranium resources were made by country and deposit category (table 2 and table 3). In addition, several comparisons of uranium production were made by countries that produced and which deposits were taken from (table 4 and table 5).

Table 2. Uranium resources by country [16].

\begin{tabular}{lrr}
\hline & \multicolumn{2}{c}{ Uranium $\mathbf{~}$} \\
\hline Country & \multicolumn{1}{c}{ RAR } & $\mathbf{I}$ \\
\hline Australia & 725000 \\
Kazakhstan & 378000 \\
Canada & 329200 \\
USA & 339000 \\
South Africa & 284400 \\
Namibia & 176400 \\
Brazil & 157400 \\
Niger & 243100 \\
Russian Federation & 172400 \\
Uzbekistan & 72400 \\
India & 48900 \\
China & 48800 \\
Others & 363300 \\
\hline Total & $\mathbf{3 3 3 8 3 0 0}$ \\
\hline
\end{tabular}

Table 3. Uranium production by deposit category [16].

\begin{tabular}{|c|c|c|}
\hline & \multicolumn{2}{|c|}{ Uranium } \\
\hline Deposit Type & RAR & $\overline{\mathbf{I}}$ \\
\hline Unconformity related & 491.6 & \\
\hline Sandstone & 999.5 & \\
\hline $\begin{array}{l}\text { Hematite breccia } \\
\text { complex }\end{array}$ & 499.4 & \\
\hline $\begin{array}{l}\text { Quartz-pebble } \\
\text { conglomerate }\end{array}$ & 163.6 & \\
\hline Vein & 156.8 & \\
\hline Intrusive & 183.7 & \\
\hline $\begin{array}{l}\text { Volcanic and caldera } \\
\text { related }\end{array}$ & 157.8 & \\
\hline Metasomatite & 304.9 & \\
\hline Others & 284.3 & \\
\hline Unspecified & 96.7 & \\
\hline Total & 3338.3 & \\
\hline
\end{tabular}


Table 4. Uranium production by producing country

[16].

\begin{tabular}{lr}
\hline & \\
\hline Country & $\mathbf{2 0 0 4}$ \\
\hline Canada & 9862 \\
Australia & 7593 \\
Kazakhstan & 5281 \\
Niger & 3443 \\
Russian Federation & 3190 \\
Namibia & 3067 \\
Uzbekistan & 2260 \\
South Africa & 534 \\
USA & 1805 \\
Others & 2568 \\
\hline Total & $\mathbf{3 9 6 0 3}$ \\
\hline
\end{tabular}

\subsection{Thorium}

\subsubsection{Physical, Chemical and Decay Properties of Thorium}

Thorium is a radioactive element that occurs naturally in the environment so background levels occur in air, water, and soil. Atmospheric thorium levels above natural background levels occur mainly from mining operations, milling, processing, phosphate rock processing, phosphate fertilizer production, coal-fired utilities and industrial boilers [18]. Water-soluble compounds of thorium include chloride, fluoride, nitrate, and sulfate salts. This compound is quite soluble in water. Dissolved thorium compounds, have a greater bioavailability than insoluble thorium compounds. The water-insoluble compounds of thorium include the dioxide, dicarbonate, hydroxide, oxalate, and phosphate salts. Thorium dicarbonate is soluble in concentrated sodium carbonate [19].

Pure thorium is a radioactive, silverywhite metal that is relatively stable in air and can retain its color for several months. When contaminated with oxides, thorium reacts slowly to gray and eventually black. The physical properties of thorium are strongly influenced by the degree of contamination with the oxide [20]. Chemically thorium is characterized by a stable +4 oxidation state, both in minerals and when dissolved in liquids. A common compound is thorium dioxide $\mathrm{ThO}_{2}$. Thorium dioxide has a melting point of 3300 ${ }^{\circ} \mathrm{C}$, the highest of all oxides, which explains some of its uses. At low temperatures $\mathrm{ThO}_{2}$ has a very low solubility which explains why thorium tends to be enriched in the oxidized zone of many thorium deposits. The solubility of thorium increases strongly when $\mathrm{pH}$ decreases weakly. At $\mathrm{pH} 3$, the solubility of thorium is up to $100 \mathrm{ppm}$ as a sulfate complex. Thorium has a large ionic radius and a high charge that prevents it from combining with most rock-forming minerals. In magmas, during partial melting and fractional crystallization in the mantle, thorium has a very incompatible behavior, similar to elements like $\mathrm{U}, \mathrm{REE}, \mathrm{Zr}, \mathrm{Nb}$ and others [21].

Thorium in nature is present in the form of one radionuclide $\mathrm{Th}-232$ as thorite $(\mathrm{ThSiO} 4)$ and thorianite $\left(\mathrm{ThO}_{2}+\mathrm{UO}_{2}\right)$, whereas after the mining process, Th-232 is usually concentrated as thorium dioxide $\left(\mathrm{ThO}_{2}\right)$ [22]. The decay scheme of Th-232 can be seen in Figure 2.

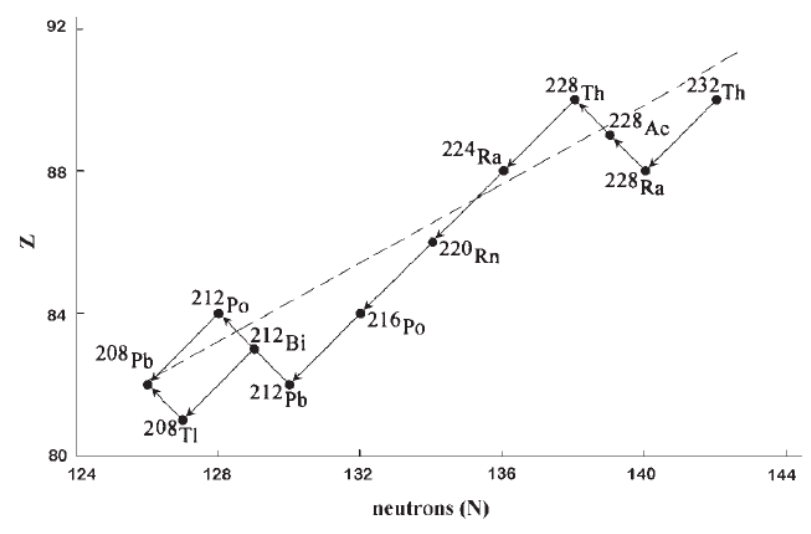

Figure 2. Th-232 Decay Series [8].

The thorium decay series can be divided into several important subsections. Some of these are Th-232 itself, Ra-228 and Rn-220. Th-232 is the most difficult to move radionuclide compared to other radionuclides. Naturally, Th-232 is a very stable oxide in the form of tetravalent or in inert silicate minerals. Ra-228 decays to produce Ac228, Th-228 and Ra-224. Rn-220 and its decay offspring can result in high radiation exposure when high concentrations of Ra-228 are found [8].

\subsubsection{Thorium Deposit}

Thorium does not occur in its metallic form in nature because it is highly oxyphile and thus occurs as an oxide (thorianite), silicate (thorite) and phosphate (often with REE). A common rare earth mineral is monazite phosphate, where the thorium content can reach up to $26 \%$. However, the most frequent concentration of thorium in monazite does not exceed $10 \%$. Other common minerals, although lower in thorium content, are xenotime and zircon. Thorium resources are generally 3-4 times larger 
than uranium resources because the Clarke concentration of thorium is 3-4 times greater than uranium. Thorium occurs frequently in nature in association with uranium. However, under certain circumstances, thorium can form deposits that contain no uranium or only very small amounts [21].

Very important thorium deposits are found in certain geological environments. Based on the TECDOC IAEA-1877, thorium deposits are divided into several categories, namely carbonatite, alkaline/peralkaline rocks, vein-type, placers and metamorphic type. Based on IAEA 2005 data, the world's reserves of thorium resources are 6078000 tTH as shown in table 6 .

Table 6. Thorium resource reserves by deposit type [20].

\begin{tabular}{lcc}
\hline Jenis deposit & Resources $(1000 \mathrm{tTh})$ & Persentase \\
\hline Carbonatite & 1.900 & 31,3 \\
Placer & 1.500 & 24,7 \\
Vein type & 1.300 & 21,4 \\
Alkaline rocks & 1.120 & 18,4 \\
Lain-lain| & 258 & 4,2 \\
Total & 6.078 & 100,0 \\
\hline
\end{tabular}

Carbonatite often appears as plugs in alkali/alkali intrusion complexes. Carbonatite is classified into coarse calcite, and fine grained calcite alvikit ( $\mathrm{Ca}$ predominance). The dolomite variety is called rauhaugite $(\mathrm{CaMg})$, and the ankeritic variety (iron-rich carbonate) is called beforsite. Molten carbonatite has an unusual composition because carbonates predominate in silica minerals (>50\% carbonate) and are enriched with incompatible elements. These minerals can be apatite, barite, vermiculite, $\mathrm{Th}, \mathrm{Nb}, \mathrm{Ta}, \mathrm{Cu}, \mathrm{Fe}, \mathrm{Zr}$, $\mathrm{Ti}, \mathrm{U}$ and others. Alkaline/peralkaline intrusions often carry a carbonatite core or plug. Geochemically this rock is characterized by excessive alkalinity and aluminum saturation. Vein-type mineralization is described as discordant mineralization which tends to be mostly in various rocks (mostly magmatic and metamorphic) occupying faults and fissures. Deposits in placers can be divided into several subtypes according to the location of the material. The less important and poorly described sediment types in the literature are those that occur in metamorphic environments. Little information is available about thorium deposits of metamorphic origin. In principle, this type consists of concentrations of thorium in metamorphosed or metasomatic rocks. The thorium carrier minerals are mostly finely dispersed in the schistosity plane, etc. The parent rocks of this type can be anatexites, migmatites, pyroxenites, gneisses and schists, as well as contact metamorphic rocks such as skarn, hornfels and marbles [21].

Thorium is distributed throughout the earth in the form of rocks and minerals, usually mixed with uranium, rare earth elements, niobium and tantalum oxides, silicates and phosphates. In veintype deposits, thorium exists as thorite (thorium silicate) or thorianite (thorium oxide). Basically there are several thorium minerals and several major thorium minerals as shown in table 7 . Among these minerals, the mineral with the largest thorium content is the rare earth mineral thorium phosphate, monazite (Ce-La-Y) which contains about $12 \%$ thorium oxide, however, on average it contains about 6-7\% thorium oxide and is currently the most widely produced source of thorium commercially. However, monazite has a different content of thorium depending on the location of the mineral [20].

Table 7. The main composition of the mineral thorium [20].

\begin{tabular}{ll}
\hline \multicolumn{1}{c}{ Ore } & \multicolumn{1}{c}{ Composition } \\
\hline Thorite & $(\mathrm{Th}, \mathrm{U}) \mathrm{SiO}_{4}$ \\
Thorianite & $\left(\mathrm{ThO}_{2}+\mathrm{UO}_{2}\right)$ \\
Thorogummite & $\mathrm{Th}\left(\mathrm{SiO}_{4}\right)_{1-x}(\mathrm{OH})_{4 x}$ \\
Monazit & $(\mathrm{Ce}, \mathrm{La}, \mathrm{Y}, \mathrm{Th}) \mathrm{PO}_{4}$ \\
Brocktite & $\left(\mathrm{Ca}, \mathrm{Th}_{2}, \mathrm{Ce}\right)\left(\mathrm{PO}_{4}\right) \mathrm{H}_{2} \mathrm{O}$ \\
Xenotime & $(\mathrm{Y}, \mathrm{Th}) \mathrm{PO}_{4}$ \\
Euxenite & $(\mathrm{Y}, \mathrm{Ca}, \mathrm{Ce}, \mathrm{U}, \mathrm{Th})\left(\mathrm{Nb}, \mathrm{Ta}, \mathrm{Ti}_{2} \mathrm{O}_{6}\right.$ \\
Iron Ore & $\mathrm{Fe}+$ rare earths $\mathrm{Th}$ apatite \\
\hline
\end{tabular}




\subsection{Uranium and Thorium in Indonesia}

Batan has mapped uranium and thorium resource reserves in Indonesia as shown in Figure 3 and table 8. The largest uranium reserves are in Kalimantan, while the largest thorium reserves are in Bangka Belitung [23].

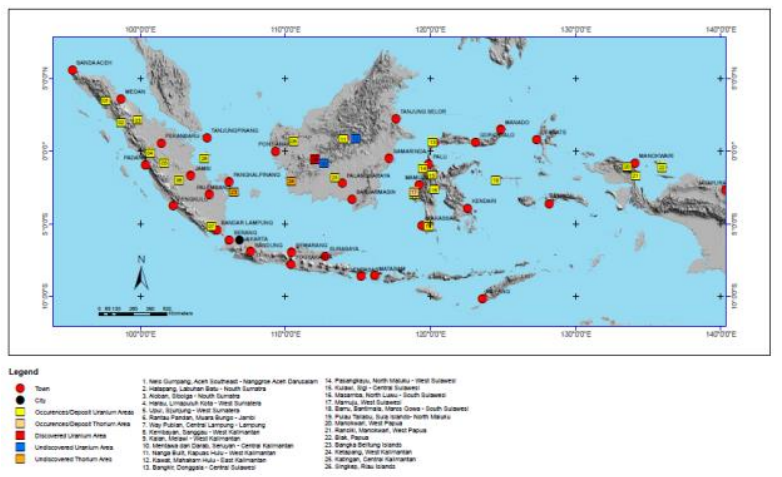

Figure 3. Map of the distribution of uranium and thorium in Indonesia [23].

Table 8. The presence of uranium and thorium in Indonesia [23].

\begin{tabular}{|l|l|l|l|l|}
\hline \multirow{2}{*}{ No } & Wilayah & Thorium (Ton) & \multicolumn{2}{|c|}{ Uranium (Ton) } \\
\cline { 2 - 5 } & Undiscovered & Discovered & Undiscovered \\
\hline 1 & Kalan - Kalimantan Barat & - & 11.868 & 5.058 \\
\hline 2 & $\begin{array}{l}\text { Ketapang - Kalimantan } \\
\text { Barat }\end{array}$ & 4.767 & - & 736 \\
\hline & $\begin{array}{l}\text { Mentawa, Darab dan } \\
\text { Katingan - Kalimantan } \\
\text { Tengah }\end{array}$ & 2.261 & 623 & 10.241 \\
\hline 4 & $\begin{array}{l}\text { Kawat, Mahakam Hulu - } \\
\text { Kalimantan Timur }\end{array}$ & - & - & 17.861 \\
\hline 5 & Bangka - Belitung & 126.207 & 2.840 & 26.939 \\
\hline 6 & Singkep, Kepulauan Riau & 433 & - & 1.298 \\
\hline TOTAL & 133.668 & 15.331 & 62.133 \\
\hline
\end{tabular}

Exploration activities have been carried out since the early 1960s, with peak activities in 1976 - 1985. Since 1996 exploration activities have been focused on the Kalan area and its surroundings in Kalimantan related to metamorphic rocks. From 2006 - 2010 exploration extended to the East Kalimantan Wire area, related to volcanic rocks. From 2011 - 2012 exploration in Papua began, in addition to that, uranium and thorium were explored as placer deposits (alluvial sand) on the islands of Bangka and Ketapang, West Kalimantan [24].

\section{Environmental Radiation Monitoring in Indonesia}

Controlled release of radionuclides into the atmosphere and aquatic environment is a legal waste management practice in the nuclear industry and related facilities [26]. Typically, controlled release of gaseous and particulate matter containing radionuclides is carried out through the chimney, although for small facilities it may be through exhaust ventilation or work hoods, for example. Controlled discharge of fluids is usually done by pipe to a river, lake or ocean, but can also be done through the normal sewer system of a small company. An essential and essential element in discharge control is regular monitoring - both at the source of the discharge and at the receiving environment - to ensure the protection of people and the environment [25].

Uncontrolled release of radionuclides into the atmospheric, aquatic, and terrestrial environments can occur as a result of nuclear or radiological accidents. Monitoring of accidental releases at the source, and especially direct monitoring of environmental pollution with radionuclides, is necessary for the assessment and implementation of measures for public protection and long-term countermeasures and emergency occupational radiation protection. In such cases, individual monitoring may be justified. In areas historically contaminated with long-lived radionuclides, monitoring is essential for community protection and as a basis for restoration activities [25].

Batan has implemented two types of environmental monitoring programs, namely environmental monitoring programs in nuclear installation areas and environmental monitoring programs in global areas. The environmental monitoring program in the nuclear installation area is intended to provide an overview of the level of radiation and environmental radioactivity before, during and after the operation of a nuclear installation. Its purpose is to prove to the public that the activities of nuclear installations during normal operation do not cause radiological impacts on the environment, especially on the communities around nuclear installations [7]. 
Global monitoring is environmental monitoring due to the regional and global distribution of radionuclides originating from natural or artificial radiation sources throughout Indonesia. The aim is to obtain basic data on radiation levels and environmental radioactivity in various samples. This basic data will be used to determine the source of radiation that causes pollution in the event of a nuclear accident, both from within the country and from abroad. The monitoring is divided into two types, namely monitoring the level of environmental radiation and environmental radioactivity. Monitoring the level of environmental radiation is obtained by measuring the dose rate of gamma radiation in the air. The result of this measurement is the dose rate of gamma radiation in units of $\mathrm{R} / \mathrm{hour}$ or Gy/hour or Sv/hour. In 2010, Batan has made a dose rate map which is the result of the measurements made as shown in figure 4 . This map will continue to be updated as more monitoring or measuring the dose rate of gamma radiation is carried out. Environmental radioactivity monitoring is obtained by measuring various types of environmental samples. The result of this measurement is radionuclide activity which is usually in units of $\mathrm{Bq} / \mathrm{kg}$ or $\mathrm{Bq} / \mathrm{l}$. An example of environmental radioactivity measurement that has been carried out by Batan can be seen in table 9 [7].

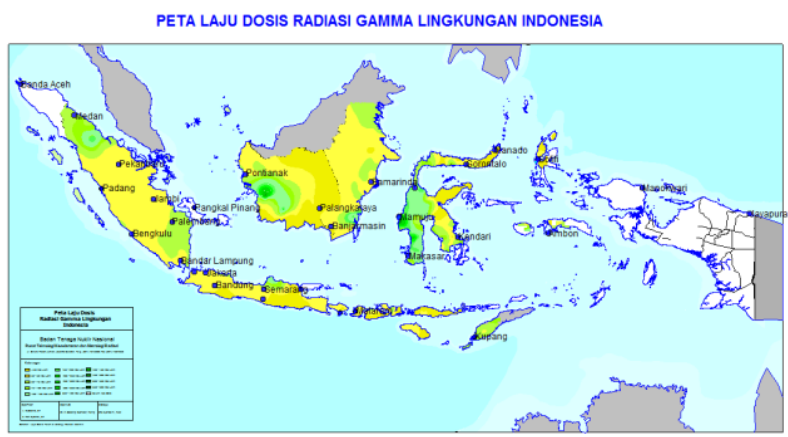

Figure 4. Gamma radiation dose rate map in Indonesia [7]

Table 9. The results of measurements of radionuclide concentrations from natural radiation sources [7]

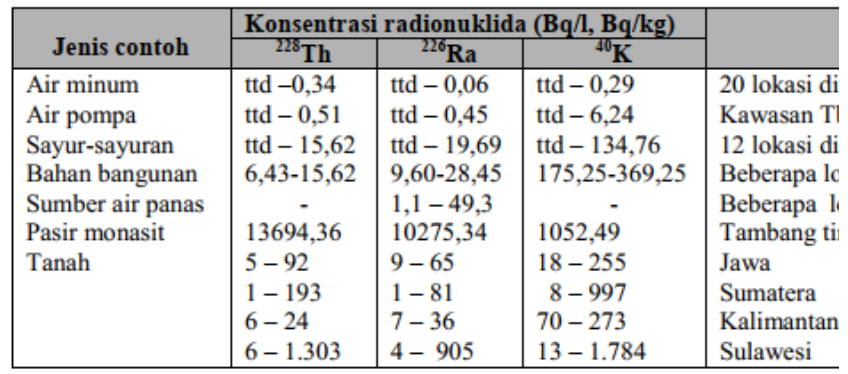

\section{CONCLUSION}

A review has been conducted on the monitoring of natural and environmental radiation in Indonesia as well as the potential of mining products (natural uranium and thorium) as a source of natural radiation. According to the IAEA's TECDOC, natural uranium and thorium are present in various types of deposits. The sandstone deposit type is the most abundant type of natural uranium deposit. While the type of carbonatite deposit is the type of deposit that contains the most natural thorium. In terms of mineral type, monazite, which is abundant in tin mines, is the largest contributor to the composition of natural thorium. In Indonesia, several exploration activities have been carried out to look for the presence of natural uranium and thorium. Kalimantan is the area with the most reserves of uranium resources in Indonesia, while Bangka Belitung is the area with the most reserves of thorium resources in Indonesia. Batan has been monitoring natural and environmental radiation in Indonesia for a long time. Batan Produces a map of the gamma radiation dose rate and the results of the calculation of radionuclides contained in environmental samples. One sample containing a high concentration of radionuclides is monazite sand from a tin mine, which contains a large amount of natural thorium, more than 1000 times more radiative than other environmental samples such as soil. So it should also be noted that natural thorium and natural uranium contained in mining products, be it monazite sand or other mining products, are radioactive and have the potential to provide more radiation exposure to mining workers, so it needs to be handled by related parties.

\section{REFERENCES}

[1] IAEA.2018. Nuclear technology review 2018. Vienna. IAEA

[2] Cooper, J. K Randle., dan R S Sokhi. 2004. Radioactive Releases in the Environment: Impact and Assessment. New York. John Willey and Sons

[3] Supriyanto, Amir. 2005. Pengukuran radioaktivitas dan radiasi-gamma lingkungan di provinsi Lampung. Lampung. J. Sains Tek

[4] UNSCEAR. 2000. Sources and effects of ionizing radiation. New York. UNSCEAR

[5] Taftazani, Agus. Sumining dan Muzakky. 2000. Sebaran radioaktivitas radionuklida 
alam dan faktor akumulasinya dalam air, sedimen dan tanaman di perairan sungai dan laut surabaya. Yogyakarta. GANENDRA

[6] Sukesi, Endang. Budi Prayitno., dan Suliyanto. 2011. Pengolahan data pengukuran radioaktivitas alpha di udara instalasi nuklir. Serpong. BATAN

[7] Sutarman. Syarbaini. Kusdiana dan Setiawan, Asep. 2010. Pemantauan lingkungan untuk keselamatan radiasi publik di Indonesia. Jakarta. Seminar Nasional Keselamatan Kesehatan dan Lingkungan VI

[8] Martin, James E. 2013. Physics for Radiation Protection. Weinheim. Wiley

[9] UNSCEAR. 1988. Sources and effects of ionizing radiation. New York. UNSCEAR

[10] Henriksen, T. Maille, H.D. 2003. Radiation and health. London. Taylor \& Francis

[11] IAEA. 2004. Radiation, people and the environment. Vienna. IAEA

[12] Yang, Xiaoping dkk. 2000. Worldwide Nuclear Explosions. Arlington

[13] Keith, Sam dkk. 2013. Toxicological Profile for Uranium. Atlanta. Agency for Toxic Substances and Disease Registry (US)

[14] Lide, DR. Frederikse, HPR. 2010. Handbook of chemistry and physics. Boca Raton. CRC Press

[15] Campbell, Kate M dkk. 2015. Biogeochemical aspects of uranium mineralization, mining, milling, and remediation. Amsterdam. Elsevier

[16] IAEA. 2009. World distribution of uranium deposits (UDEPO) with uranium deposit classification (IAEA-TECDOC-1629). Vienna. IAEA
[17] IAEA. 1998. Classification of uranium reserves/resources (IAEA-TECDOC-1035). Vienna. IAEA

[18] Keith, Sam dkk. 2019. Toxicological Profile for Thorium. Atlanta. Agency for Toxic Substances and Disease Registry (US)

[19] Weast, RC. 1983. Handbook of chemistry and physics. Boca Raton. CRC Press

[20] Dewita, Erlan. 2012. Analisis potensi thorium sebagai bahan bakar nuklir alternatif PLTN. Jakarta. Jurnal Pengembangan Energi Nuklir Vol. 14 No. 1, Juni 2012

[21] IAEA. 2019. World thorium occurrences, deposits and resources (IAEA-TECDOC1877). Vienna. IAEA

[22] Falciglia, Pietro P dkk. 2017. Stabilisation/Solidification of soils contaminated by mining activities. Amsterdam. Elsevier

[23] Bastori, Imam. Birmano, Moch Joko. 2017. Analisis ketersediaan uranium di Indonesia untuk kebutuhan PLTN tipe PWR 1000 $M W e$. Jakarta. Jurnal Pengembangan Energi Nuklir Vol. 19, No. 2, (2017) 95-102

[24] Sumaryanto, Agus. 2012. Uranium and thorium exploration activities and their processing research in Indonesia. Jakarta. Batan

[25] IAEA. 2005. Environmental and source monitoring for purposes of radiation protection (Safety Guide No. RS-G-1.8). Vienna. IAEA

[26] IAEA. 1995. The principles of radioactive waste management (safety series no. 111-F). Vienna. IAEA 